\title{
DETERMINING THE ROLE OF BANKS IN THE FINANCING OF INNOVATIVE DEVELOPMENT PROCESSES OF THE ECONOMY
}

\author{
Diana Zavadska' \\ Odessa National Economic University, Ukraine
}

\begin{abstract}
The paper states that the success of Ukraine's development, in the context of the transition to the model of Ukraine's innovative development, contributes to a clear choice of priorities, among which the main thing is to ensure high rates of economic growth. The role of banks in reproductive processes is proved, which corresponds to modern problems of innovative development of the Ukrainian economy. The scientific approaches of various economic theories (neoclassical, monetarist, Keynesian, institutional, and the concept of financial mediation) are investigated. Advantages of studying the world experience of economic theory are to determine its connection with banking activities. But this does not entail the task of carrying out a complete historical study of all economic concepts relating to the impact on the economic development of the financial market itself and its subjects. The author highlighted the task of studying the relationship of development, participation of banking sector actors, and trends in the development of new paradigms in the theory of financial intermediation. The purpose of the article is to conduct an analysis of the theoretical provisions on determining the role of banks in financing innovative development of the economy. Methodology. The information base of the research is the results of scientific research results in determining the influence of the monetary sphere, interest rates, production, investments, and state on the processes of reproduction of the economy, published in monographic studies and publications in periodicals. During the research, methods of logical generalization, comparative analysis, system approach that takes into account the dynamic functional dependence between the state of the whole, development and the balance of its constituent elements are used. Results. The article emphasizes that the issue of activating the activity of banks in the investment market has become particularly significant. A critical analysis of research and development of leading scholars has led to the conclusion that there is no generally accepted idea of determining the place and role of banks in the growth of the country's economy. It is established that the representatives of neoclassical theories of mediation most thoroughly considered the theoretical positions regarding the definition of the role of banks in the revitalization of economic growth. Practical implementation. The practical significance is in the fact that scientific research clearly, understandably, and consistently proves the importance of the participation of banks in reproductive processes. The results obtained in the future will be used to develop recommendations for defining the directions of interaction between banks and enterprises of the real sector of the Ukrainian economy in order to enhance the processes of bank financing of innovation development of the economy. Value/novelty. The article substantiates the special role of banks in economic growth, which is determined by the increase in business activity, the impact on the increase of money supply in circulation, the priority of credit operations aimed at the country's crisis recovery.
\end{abstract}

Key words: economic theories, bank, role, financing, economic growth, innovative development.

JEL Classification: E1, O1, O2, O3

\section{Introduction}

A particular task for the development of Ukraine's modern economy is to increase the role of banks in shaping the necessary resources for implementing innovation policy. In order to ensure the innovative development of the domestic economy, necessary are the creation of new production capacities, renewal of

Corresponding author:

${ }^{1}$ Department of Banking, Odessa National Economic University.

E-mail: zavadska.diana@ukr.net fixed assets, which is crucial for the growth of labour productivity, resource conservation, and ensuring the competitiveness of Ukrainian products. These transformations require large-scale innovation-oriented investments, provided with appropriate sources of financing. In this regard, the issues of development of bank loans, as sources of funding for projects of 
modernization of the real sector of the economy, are of particular importance.

Major difficulties in implementing the innovative potential of the Ukrainian economy actualize the need to increase the role of bank loans and, accordingly, the banks and they are characterized by insufficient volumes of domestic resources of domestic enterprises, low rates of structural transformations, inefficient government support, lack of policies to stimulate investors, imperfect legislative framework, high credit risks, associated with insufficient solvency of enterprises, underdevelopment of innovation and investment infrastructure.

\section{Problem statement}

Due to the objective need to attract investment resources to innovative programs and projects focused on priority areas of economic development in Ukraine, the issue of activating the activities of commercial banks in the investment market has gained a special significance. Participation of the banking sector in solving a multifunctional and complex problem of the formation and development of innovative business in Ukraine requires the scientific basis for the development and implementation of an effective investment and financial policy of commercial banks.

The necessity to fulfil the abovementioned important strategic objectives of the innovative development of the domestic economy requires to define the role of banks in reproductive processes that would meet the current specific conditions of global financial instability and the objectives of the innovative development of Ukrainian economy and to form the theoretical basis for practical measures of the impact of modern banks on economic growth, which determined the purpose of our study.

The purpose of research is to conduct an analysis of the theoretical provisions on determining the role of banks in financing innovative development of the economy.

\section{Results}

The analysis of economic literature made it possible to conclude that the problems of determining the place and role of banks in the reproduction process are discussed by researchers for a long time, but there is no generally accepted opinion. In our view, among a large number of different theories, which substantiate scientific approaches to determining the impact of banks on economic growth, the role of banks is most thoroughly disclosed in the neoclassical, Keynesian, institutional economic theories and paradigms of financial intermediation.

\subsection{The role of banks in neoclassical economic} theory

Representatives of neoclassical school (Böhm-Bawerk, 1890; Menger, 1871; Fisher, 1907; Wicksell, 1935; Wicksell, 1936; Hicks, 1939) considered necessary to conduct a more detailed study of conditions of market equilibrium, studying the mechanism of functional relations in the field of monetary and credit relations. I. Fischer was a supporter of ideas for regulating the investment cycle through monetary policy. In the research paper "The Theory of Interest" (Fisher, 1930) he made an attempt to create an investment model of the economy and considered the reproduction regulator as the difference between the expected rate of return on investment and the rate of interest. I. Fischer emphasized that for investments it is necessary that the rate of income necessarily exceeds the rate of interest.

Further development of the provisions of the neoclassical school has been affected by such important factors as the aggravation of problems of resource limitation, false choice, and asymmetry of information. Actions of central banks to stimulate the supply of money, which ensure the continuity of reproduction, led to an increase in the cost of obtaining fast and reliable information and related credit risks. The above resulted in lower readiness of banks to lend to innovative projects of the real sector of the economy.

Followers of the neoclassical direction determined the money supply as the single most important factor affecting the level of production, employment, and prices, emphasized that the change in the money supply directly affects aggregate demand and nominal GDP. As the main factor of changes in economic activity, they recognized the changes in solvent demand for goods and services caused by the inability to stabilize the cash flow in the absence of complete information on future development.

\subsection{The role of banks in monetarist economic theory}

The next direction of economic theory, which determines the role of banks in economic development, is the monetary theory. Theoretical studies of monetarists (Mill, 1848 (1909); Mill, 1867; Pigou, 1927; Marshal, 1923; Marshal, 1879; Friedman, 1948) developed on the grounds of the need to develop special activities (institutional measures) and increase state expenditures aimed at reducing information risks and developing the credit market, as well as open market operations, which have an impact on banks' reserves and lending rates.

M. Friedman and other monetarists (Friedman, 1968; Friedman, 1970; Johnson, 1971; Thornton, 1995) considered a relatively high share of deposit money in the money supply as the basis of the influence of the central bank on the corporate sector. Therefore, they attached a special importance to administrative methods of influencing the lending activity of banks and the regulation of money supply. The identified methods, in their opinion, should influence the distribution of resources between industries, supporting economic activity, which will increase the role of banks in innovative economic development. 


\subsection{The role of banks in Keynesian economic} theory

Although representatives of Keynes's theory (Keynes, 1936; Stiglitz, Sen \& Fitoussi, 2008 (2016); Tobin, 1970; Tobin, 1981 (2004)) preferred the study of production processes in their research papers but did not assign the essential role to banks and their influence on reproduction processes. They argued that the basis of economic growth is an increase in the volume of government spending and investment, rather than the activities of business entities and banks.

Consequently, the supporters of the Keynesian theory in their studies devoted a considerable attention to determining the role of the state in macroeconomics. In contrast to the neoclassicists, who determined the basis of economic development in exchange, the Keynesian theory's representatives did not deny the importance of exchange but determined the dominant role of the production process, which creates added value.

Keynesians, highlighting the special role of the central bank, argued that with the help of state intervention in the money market it is possible to regulate the interest rate in the long run. In their view, monetary policy should actively promote economic growth on the basis of providing a sufficient amount of money in circulation and, consequently, the maximum reduction of the interest rate. Later, the followers of this theory argued that money is important, but economic management with monetary policy is not so effective means of stabilization as a fiscal policy. Thus, the Keynesians underestimated the role of banks and their influence on reproductive processes and considered the basis of economic growth as an increase in government spending or public investment, rather than an increase in money in circulation and volumes of bank loans.

\subsection{The role of banks in institutional economic theory}

New trends in the development and change of banks' role in reproduction processes are defined in their scientific works by representatives of the institutional direction of economic theory.

It should be noted that in the early stages of the development of the theory of institutionalism, its representatives denied the possibility of a positive role of banks in financing the economy. For example, the classics of institutionalism (Veblen, 1904 (2007); Commons, 1934; Galbraith, 1967 (2008)) assessed bank capital as parasitic and denied the positive influence of banks on the processes of reproduction of the economy. Under the institutions, they understood, first of all, the socio-psychological phenomena of the life and activities of people who rely on their habits and are enshrined in legal acts, that is, they investigated the economy on the basis of law and politics.

Subsequently, representatives of neo-institutionalism (Coase, 1990 (1993), North, 1990; North, 2005) acknowledged the possibility and need for state influence on monetary, financial, and credit institutions. They investigated the banking business using the categories of "consumption", "utility", and "alternative costs".

Later, under the influence of W. Mitchell (Mitchell, 1913 (1929)), representatives of institutionalism began to recognize the possible and necessary state influence on the development of the economy based on monetary, financial, and credit factors, in conjunction with socio-cultural problems and taking into account psychological aspects.

The development of industry, the strengthening of the role of banks in the financial market, the changing conditions of the functioning of the economy under the influence of globalization, information and communication technologies have become the subject of an analysis of the main provisions of the theory of institutionalism, which was formed as a special direction of economic theory in the early twentieth century.

The basis of the standard provisions of the modern institutional-evolutionary theory was the recognition of the growing role of banks in economic development. The most important role here was played by J. Schumpeter (Schumpeter, 1912 (1982)), who unambiguously linked banks with the nature of market economies: "The banker, therefore, is not so much primarily a middleman in the commodity "purchasing power" as a producer of this commodity ... He has himself become the capitalist par excellence ... He is essentially a phenomenon of development, though only when no central authority directs the social process. He makes possible the carrying out of new combinations, authorises people, in the name of society as it were, to form them. He is the ephor of the exchange economy."

Consequently, the recognition of the essential role of banks in economic development has become one of the standard provisions of modern institutionalevolutionary theory.

The merit of the representatives of this theory, especially J. Schumpeter, is the study of issues of functioning of the banking sector, caused by the transition from the state monopoly to banking autonomy, issues of interconnection of banks and the real sector of the economy, the formation of the market of banking products and services, which, in our opinion, became a prerequisite for intensifying the participation of banks in financing the needs of innovative development of the economy (Schumpeter, 1934 (2011); Schumpeter, 1939).

\subsection{The role of banks in financial intermediation concepts}

At the end of the twentieth century, a new concept of the theory of financial intermediation begins to form in relation to determining the role of banks in activating the processes of economic reproduction, the essence of which is to consider the bank as a growth multiplier (Hodgman, 1961; Hodgman, 1963; King, 1986; Sinkey, 1979; Sinkey, 1992). 
This concept is based on the effect of deposit expansion - the expansion and growth of deposits under the influence of issued loans, also known as the multiplier effect, on the basis of which investment leads to the growth of production through the chain of technological connections in the economy.

It should be noted that the effect of the banking multiplier was noted in the research by J. Schumpeter. He emphasized that banks finance new loans when creating new deposit money. That is, in all cases when a borrower has received a new loan from a bank, this loan is issued through the creation of a new deposit for the same amount and on behalf of the same client, which was considered a very serious factor in the vulnerability of financial systems.

Note that in modern neoclassical theories of intermediation in providing funds available for lending, banks are considered as intermediaries in the distribution of real savings. The process of lending in this version begins with the attraction of banks deposits from depositors at the expense of real resources from their previously accumulated savings and ends with the provision of the same real resources on loans to borrowers. But in real terms, the functioning of financial intermediaries of such institutions simply does not exist. Modern banks create new money, which, in turn, creates conditions for increasing the volume of financing of innovative needs of economic development during the period of growth. But at the same time, banks, with the insufficient regulation of borrowing and borrowing processes, accumulate risks.

From the beginning of the twenty-first century, under the influence of the development of innovations on the basis of new information and communication technologies, globalization, knowledge economy, researchers began to pay more attention to the participation of banks in financing innovations. For example, the role of the banking sector in financing innovation has been evaluated in studies by a number of analysts. In the work of A. Herrera and R. Minetti (Herrera \& Minetti, 2007), the influence of banks on innovation through lending is considered. The authors emphasize that the duration of credit relations positively affects the innovative activity of companies. This effect is more important for food products than for technological innovations. Researchers also note that banks do not have special knowledge to develop and evaluate innovation, but simply finance those investments that create conditions for the introduction of new technologies.

In their scientific works, researchers E. Alemani, C. Klein and others (Alemani, Klein, Koske, Vitale \& Wanner, 2013) emphasize the significant role of the banking sector in the innovative development of the technological process. Innovation activitywas stimulated mainly by intergovernmental banking deregulation. The research of other authors was conducted in the plane of assessment of the impact of banking deregulation on the level of innovation risk. In the course of this study, the authors conclude that national and intergovernmental banking deregulation has a significant impact on the level of innovation risk for new private firms, while it does not affect the investment of government firms and mature private firms.

In terms of activation of innovative processes and the need of their financing, an important issue is the definition of limits and possibilities of the presence of banks in the venture market. In the research of T. Hellmann (Hellmann, Lindsey \& Puri, 2008), the role of the bank as a venture investor is investigated in detail. It has been shown that banks are oriented on those enterprises, which in the future can switch to banking services. Thus, banks are given the opportunity to get a synergistic effect from the combination of venture and banking business, which gives them an advantage over venture companies. This trend was proved on the basis of data analysis of specific enterprises: the largest increase in lending was observed in those companies, which investments were carried out by banks, while those companies that received venture capital from venture companies showed fewer dynamics.

\section{Conclusions}

The obtained results allow formulating the conclusions that:

1. The neoclassical direction of economic theory, formed in the conditions of development of the industrial-market economy, paid attention to the study of conditions of market equilibrium, the mechanism of functional relations in the field of exchange, that is, representatives of the neoclassical school in their scientific works pay more attention to the processes of exchange than their predecessors.

2. Monetarists grounded the role of monetary policy as the main instrument that determines the level of economic activity and the possibility of financing innovation.

3. Economic stability, in the opinion of the Keynesians, is ensured by the state support through the regulated system of relations between the state and the banks, by encouraging investment and innovative bank loans with a low-interest rate.

4. Determining the role of banks as intermediaries passively performing the technical function of monetary mediation of exchange transactions in the financial market is unlawful in accordance with the institutional direction of economic theory.

5. According to the views of the representatives of the theories of financial intermediation, the role of banks is manifested in:

- increased business activity, the ability to influence the growth of money supply in circulation, the promotion of economic growth, and the country's crisis recovery, 
which requires qualitative and adequate regulation of their activities at the micro and macro levels; - the possibility of venture investments with the further involvement of companies in banking services. However, the priority, when performing the role of a venture investor, is the implementation of credit operations.

6 . The analysis of the content and peculiarities of each of the theories considered in the article allows concluding that it is precisely the works of scientists-representatives of the neoclassical theories of intermediation that the most thoroughly consider the theoretical positions that further will be used by us in determining effective areas of interaction between banks with clients, developing fundamentally new banking instruments for investing in innovative business, the use of which will help to increase the role of banks in the innovative development of Ukraine.

\section{References:}

Böhm-Bawerk E. (1890). Capital and Interest: A Critical History of Economical Theory (W. Smart, Trans) (3 vol. set). London: Macmillan \& Co.

Menger C. (1871). Principles of Economics. New York: University Press.

Fisher I. (1907). The Rate Interest. Its Nature, Determination and Relation to Economic Phenomena. New York: The Macmillan Company.

Fisher I. (1930). The theory of interest, as determined by impatience to spend income and opportunity to invest it. New York: The Macmillan Company.

Wicksell K. (1935). Lectures on Political Economy. Money (vol. 1). London: George Routledge \& Sons, Ltd.

Wicksell K. (1936). Lectures on Political Economy. Interest and Prices (Vol. 1). London: George Routledge \& Sons, Ltd.

Hicks J. (1939). Value and Capital: An Inquiry into Some Fundamental Principles of Economic Theory. Cambridge: University Press.

Mill J. (1848 (1909)). Principles of Political Economy with Some of Their Applications to Social Philosophy (eds. W. Ashley \& M. Com). London, New York [etc.]: Longmans, Green, and Co.

Mill L. (1867). Credit Cycles and the Origin of Commercial Panic. Manchester Statistical Society.

Pigou A. (1927). Industrial Fluctuation. London: Macmillan \& Co.

Marshal A. (1923). Money, Credit and Commerce. London: Macmillan \& Company.

Marshal A. (1879). Economics and Industry. London: Macmillan \& Co.

Friedman M. (1948). A Monetary and Fiscal Framework for Economic Stability. American Economic Review, vol. 38, June, pp. 245-264.

Friedman M. (1968). The Role of Monetary Policy. American Economic Review 58, no. 1, pp. 1-17.

Friedman M. (1970). The Social Responsibility of Business Is to Increase Its Profits. New York Times Magazine, vol. 13, September.

Johnson H. (1971). The Keynesian Revolution and the Monetarist Counter Revolution. American Economic Review 61, no. 2, pp. 1-14.

Thornton J. (1995). Friedman's Money Supply Volatility Hypothesis: Some International Evidence. Journal of Money, Credit, and Banking 27, no. 1, pp. 288-292.

Keynes J. (1936). The General Theory of Employment, Interest and Money. London: Palgrave Macmillan.

Stiglitz J., Sen A., Fitoussi J.-P. (2008 (2016)). Neverno otsenivaya nashu zhizn: Pochemu VVP ne imeet smysla? Doklad Komissii po izmereniyu effektivnosti ekonomiki i sotsialnogo progressa [Mismeasuring our lives: why GDP doesn't add up? Report by the Commission on the measurement of Economic Performance and Social] (I. Kushnarevoy \& T. Drobyshevskaya, Trans). M.: Izd-vo Instituta Gaydara. (in Russian)

Tobin J. (1970). Money and Income: Post Hoc Ergo Propter Hoc. Quarterly Journal of Economics, vol. 84, May, pp. 301-317.

Kilyachkov N. (1981 (2004)). Dzheyms Tobin: rol deneg i finasov v makroekonomicheskikh protsessakh [James Tobin: The Roles of Money and Finance in the Macroeconomic Processes]. Mezhdunarodnyy bukhgalterskiy uchet - The international accounting, vol. 6(66), pp. 39-45. (in Russian)

Veblen T. (1904 (2007)). Teoriya delovogo predpriyatiya [The Theory of Business Enterprise]. (Ya. Kazhdan \& V. Grebennikov, Trans). M.: DELO, Tsentr evolyutsionnoy ekonomiki (Rossiya), Akademiya narodnogo khozyaystva pri Pravitelstve RF. (in Russian)

Commons J. (1934). Institutional Economics. Its Place in Political Economy. New York: The Macmillan Company. Galbraith J. (1967 (2008)). Novoe industrialnoe obshchestvo [The New Industrial State]. Izbrannoe - Selected works. M.: Eksmo. (in Russian)

Coase R. (1990 (1993)). Firma, rynok i pravo [The Firm, the Market and the Law]. M.: Delo LTD: Catallaxy. (in Russian)

North D. (1990), Institutions, Institutional Change and Economic Performance, Cambridge: Cambridge University Press.

North D. (2005). Understanding the Process of Economic Change. Princeton: Princeton University Press. 
Mitchell W. (1913 (1929)). Business Cycles: The Problem and Its Setting. New York: National Bureau of Economic Research, Inc.

Schumpeter J. (1912 (1982)). Teoriia ekonomichnoho rozvytku [The Theory of Economic Development]. M.: Prohres. (in Ukrainian)

Schumpeter J. (1934 (2011)). Teoriia ekonomichnoho rozvytku. Doslidzhennia prybutkiv, kapitalu, kredytu, vidsotka ta ekonomichnoho tsyklu [The Theory of Economic Development. An Inquiry into Profits, Capital, Credit, Interest, and the Business Cycle]. (V. Stark, Trans). Kyiv: VD "Kyievo-Mohylianska akademiia". (in Ukrainian)

Schumpeter J (1939). Business cycles. A Theoretical, Historical and Statistical Analysis of the Capitalist Process. (ed. R. Fels). New York, Toronto, London: Mc Graw-Hill Book Company.

Hodgman D. (1961). The deposit relationship and commercial bank investment behavior. Economics and Statistics, 43, August, pp. 257-268.

Hodgman D. (1963). Commercial bank loan and investment policy. Champaign, Bureau of Economic and Business Research, University of Illinois.

King S. (1986). Monetary transmission: Through bank loan or bank liabilities? Journal of Money, Credit and Banking, vol. 18, no. 3, pp. 290-303.

Sinkey J. (1979). Problem and Failed Institutions in the Commercial Banking Industry. Greenwich: JA1 Press.

Sinkey J. (1992). Commercial Bank Financial Management in the Financial-Services Industry (6th ed.). Macmillan Perspective Publishing Company.

Herrera A. \& Minetti R. (2007). Informed Finance and Technological Change: Evidence from Credit Relationship. Journal of Financial Economics, vol. 83, no. 1, pp. 223-269.

Alemani E., Klein C., Koske I., Vitale C. \& Wanner I. (2013). New Indicators of Competition Law and Policy in 2013 for OECD and non-OECD Countries. OECD Economics Department Working Papers.

Hellmann T., Lindsey L. \& Puri M. (2008). Building Relationships Early: Banks in Venture Capital. Review of Financial Studies, vol. 21, no. 2, pp. 513-541. 